\title{
Study on Charging Management in Colleges and Universities
}

\author{
Tang Yi, Ji ningning, Yang Wen \\ Panzhihua University, Panzhihua, China
}

Keywords: colleges and universities, charge, problems, improvement measures

\begin{abstract}
In this paper, taking the charging management in colleges and universities as the research object, the problems existing in college charging work has been analyzed deeply, and the improvement measure have been proposed to solve the problems. The proposed improvement measures can effectively solve the problems in the charging work of colleges and universities, so as to improve the financial management level and efficiency of colleges and universities.
\end{abstract}

\section{Introduction}

In recent years, the scale of college and university enrollment has been expanding. The Finance Department of colleges and universities, as a sector of dual function, plays an important role in financial work and student management. Under the guidance of the "Five Development Concept" put forward in 2015, the charge management of colleges and universities found its own way of development. Implementing the "Five Development Concept" is an important program of charge work in colleges and universities during the "13th Five-Year Plan". With the continuous expansion of the scale of education at colleges and universities, the significant growth of student population, the varied categories of enrollment and the diversified fee standards, charge work has proved to be more and more crucial in financial work of colleges and universities. This has alleviated the underfunding problem of colleges and universities remarkably and played an important role in the rapid yet healthy development of colleges and universities [1]. However, there are still many problems plaguing their charge work. Student charge management in colleges and universities is a traditional work of basic education management, which is trivial and resource-consuming. The deepening reforms of higher education institutions, increasing expansion of education scale, and diversifications of education standards have been perplexing items and standards of fees that students have to pay, causing further remarkable increases in charge work of the Finance Department in colleges and universities and making the work tougher and tougher. Therefore, an effective way of improving charge efficiency and the management level of college students is to develop a charge management system by adopting advanced information technology.

\section{Problems Existing In College Charge Work}

\subsection{The charging system features large and non-standardized data with some special cases} from irregular students in particular

The expansion of colleges and universities that offer various levels of programs for students led to a very large volume of data in the charge system. Charge items and standards have many disparities among different grades, departments and professions. There are even disparities within the same department and the same grade. In addition to that, some students have special conditions that lead to changes in charge items and standards, such as duration policy of tuition, absences, reentry and major changing. These different problems make charge work in colleges and universities much harder.

2.2 The management and operation mechanism of the charging information system is not well-established because the work of departments in colleges and universities is not coordinated

Due to the increases in the number of students, the total amount of fees surged sharply, making 
problems of charging more and more complex, which aggravated and complicated management work. Colleges and universities set charging as the natural responsibility of the financial sectors, while the teaching affairs office, student affairs office, logistics department, schools and departments are not well-involved [2]. The charge management system is not well-established, work responsibility and distribution is not clear, and different sectors shirk their responsibilities and blame it on each other. Such consequent inconformity brought impacts on the efficiency of charging. Meanwhile, there are shortages in information communication and reminder of arrears. Students charging refers to a great deal of information, such as the standard of accommodation fees from Logistics Department, school roll information and credit system from Teaching Affairs Office, information of student loans and reliefs from Student Affairs Office, registration information from every department, etc. So far the sharing of information and resources has not been done, and the communication of information is not enough. Every school and department, as the most direct management sector for students, is not directly responsible for the charge work and not highly motivated to ask for the payment because of thoughts of irrelevancy of tuition income [3]. Thus, disjointed management and tardiness of work are unavoidable, and some students take chances and default in their payment as long as possible. The charging business pertains to every student and will not be completed smoothly without the help of and efficient collaboration with other departments.

\subsection{Colleges and universities have no punishment for students who owe many fees. The loophole in management created an awful atmosphere of payment}

Tuition is one of the main sources of school business income. The condition of collecting full tuition fees timely by local colleges and universities affects the planned progresses of teaching, scientific research and other work. Students' arrearage is a common problem that colleges and universities are faced with after their expansion. The rising arrear rate will cause a direct impact on the budget income of colleges and universities, as well as the schools' working order and development. Therefore, the problem of malicious arrears requires highly concentrated focus. As what is aforementioned, to a large extent, the loophole of undemanding charge management is a good helper to those malicious arrears among all arrears. Due to the relevant regulation, delayed payment does not produce any overdue fine, which opens the door for students who claim to be living in poverty with false papers. Generally, the Student Handbook of colleges and universities stipulates that only when a student has paid his tuition fees, will he get his status as a student at the beginning of the new academic year, which is known as "payment first, registration later". Students are only allowed to have full access to facilities after registration. However, the fact runs in the opposite direction [4]. The students who do not pay can register, attend classes and take examinations as those who have paid. They can also be granted scholarship, student loans, work-study program, subsidy, tuition relief, and so on. Consequently, the students' incentive to pay tuition fees will be dampened. Since the charge work of colleges and universities is faced with aforementioned problems, how can these problems be solved? The following steps can be taken to improve the situation.

\section{Improvement Measures}

\subsection{Get basic information work well done.}

The Finance Department should get its basic work well done and ameliorate the charging procedures to deal with mounting work, heavy burden, large volume of data and outdated charging method. There are several types of basic work that must be completed: Firstly, colleges and universities should choose a set of charging software that can easily meet regular charging needs. Secondly, take the student ID as the only confirmation symbol by using the advantage of unified student ID management on campus. Thirdly, confirm the charge items and standards of different students. Fourthly, before the check-in of every academic year, the Finance Department should inform every student of charge items and standards of each program and time and place of payment 
through various possible approaches. Fifthly, after the collective charge work, the amount and the list of arrears should be summed up, and the reminder should be sent to the corresponding students in cooperation with relevant function sectors.

\subsection{Make the responsibility of every sector clear and definite and perfect the charge management information system.}

The actualization of colleges' well-established charge management system and clear-cut charging responsibilities of every division requires a sound charge management and operating mechanism that can help the colleges complete the charge work more smoothly through coordinated and close cooperation between every relevant sector. Financial Department: Centrally administer charge work, and constitute internal charge management documents. State policies and rules of charging clearly; handle procedures of checking, setting-up, and reporting for approval on charge projects; publish charge items and standards timely; organize the work of collecting fees and report the condition of students' payment timely to the Teaching Affairs Office, schools, departments and other relevant sectors so as to do well in registration work of students in the new semester; bulletin the condition of charging progresses and arrears timely through briefing of charge work and online financial query platform[5]. Student Affairs Sector: In cooperation with schools and departments, publicize national charging policies, strengthen students' integrity and civil education, and prompt students to pay in accordance with the provisions. Remind students of arrears through financial aids for poverty-stricken students, student evaluation, reward and disposition. Be responsible for the management of student loans, guide students to handle loan procedures, and instruct students to be honest and punctual enough to repay the debt. Teaching Affairs Office: Do the work of students' status management to the best of its ability and inform the Finance Department of IDs, names, professions and other information of the freshmen, and changes of students status like suspension, dismissal and major transfer of the students in other grades; work with the schools to do well in registration work at the beginning of every new academic year and refuse the registration of delinquent students that are not authorized. Logistics Department: report standards of accommodation fees as well as the transfer information in the dormitory to the Finance Sector. Schools and departments: do a good job of students' ideological education, organize students to pay in accordance with the designated time; create dynamic files of poverty-stricken students and grant them subsidies on the basis of clear situation after conscientious investigation; take active and effective measures to do a good job of payment for delinquent students. The reform and development of the charging approaches in colleges and universities must rely on the building of an information platform. The well-done work of information docking with every sector is the first prerequisite and necessary requirement for the development of charge management in colleges and universities. College student management is complex and cumbersome, especially the charge management work which involves a wide range of complex businesses. Given such business characteristics, the college fees management sector should have coordinated cooperation and active communication with various sectors to develop themselves on the basis of adhering to principles and guaranteeing the security of funds.

\subsection{Strengthen exchanges and training, and improve the quality of financial staff.}

With the financial reform of the institutions and the promulgation of the new Accounting System in Colleges and Universities, China's colleges and universities now have higher requirements on the professional knowledge of financial staff who must grow into financial managers with more professional knowledge than simple practical accountants. As a result, the charge management staff should enhance the demands on themselves, strengthen their own business learning and improve their management awareness. While financial knowledge is required, they also need to widen their perspectives and strengthen communication with other enterprises and institutions to learn advanced management models and methods and understand new information and technological innovation. Doing that is to accurately grasp the future direction of financial development and determine how to do a better job of charge management in the development of colleges and universities. The financial sectors of colleges and universities should also arrange training for the financial staff, not only 
business training, but also ideological construction and current affairs analysis. It is necessary to understand social dynamics and keep up with the social tide, so as to have strong thinking and learning ability in university accounting reform consistently.

\section{Conclusions}

The charge management should be synchronized with the accounting and reform of public institutions and colleges, so as to improve social responsibility consciousness, and absorb the advanced system and means from domestic and foreign to make the charge management "opening" development. At the same time, we should strengthen communication with other functional departments of the school, cooperate with each other. In the process of building the "Internet +" mobile campus platform, we should improve the means of charging to keep it innovative development. And strengthen the connection between the network payment system and the management system of functional departments to realize paperless "green accounting". And also strengthen communication with teachers and students, and pursue a more "people-oriented", harmonious "green management”.

\section{References}

[1] Diao Mingsu. Problems of and Countermeasures to Charge Management in Colleges and Universities under the New Situation [J]. Accounting Learning, 2016(11): 188-190.

[2] Wang Hong. Thoughts on the Internal Control of Charge Management in Colleges and Universities in Internet Age [J]. Communication of Finance and Accounting, 2015 (29): 127-128.

[3] Sheng Qijie. Exploration of New Model of the University Financial Management in E-times/Integration of Charge Management in Colleges and Universities [D]. Northwestern Polytechnic University, 2004.

[4] Huang Shizhong. Accounting Explanation Driven by Five Ideas [J]. New Financial Management, 2016 (1): 46-47.

[5] Zeng Xianghong, Wang Shuangxi, Chen Zhihong. Problems of and Countermeasures to College Students’ Arrears [J]. Heilongjiang Researches on Higher Education, 2005(1) 656-667. 